\title{
Roman Rosdolsky Kapitalen i almenhed og de mange kapitaler
}

Gennem en analyse af de to Marx-værker »Grundrisse« og »Kapitalen« påviser artiklens forfatter betydningen af begrebet »kapitalen $i$ almenhed .

Abstraherer vi fra konkurrencens »fordrejelser« og fra dens følgefremtrædelser, når vi frem til »kapital som sådan « eller »kapital i almenhed «.

»Kapital i almenhed « bliver således de mange kapitaler betragtet udfra deres falles bestemmelse: valoriseringsegenskaben; altså betragtet ud fra det forhold, at kapitalen ikke alene genskaber og tilegner den genskabte værdi, men også nyskaber og tilegner sig den nyskabte værdi.

Hvad betyder begrebet »kapital i almenhed«? Hvilket abstraktionsniveau foregår analysen på?

* Roman Rosdolsky, 1898-1967, har bl.a. været medarbejder ved »Marx-Engels-Instituttet « i Moskva i 1930 'erne (inden udrensningerne). Den efterfølgende artikel blev oprindelig offentliggjort i 1953 i det schweiziske tidsskrift Kyklos. 
Vi vil til at begynde med nøjes med det svar, som vi finder i Marx's brev til Kugelmann den 28. december 1862. Indskrænkningen til »kapitalen i almenhed « - hedder det der - udelukker betragtningen om kapitalernes konkurrence og om kreditvæsenet. ${ }^{1}$ I konkurrencen har vi at gøre med »en kapitals aktion på kapital«; den forudsætter en flerhed af kapitaler; medens »kapitalen fremtræder som alment element i forhold til de enkelte kapitaler « i kreditten. ${ }^{2}$ I begge tilfælde drejer det sig om konkrete kapitalers virkelige bevægelse - om kapitalen i dens realitet, ikke i dens »ideale gennemsnit «. ${ }^{3}$ I Grundrisse læser vi, at »kapital eksisterer og kan kun eksistere som mange kapitaler, og dens selvbestemmelse fremtræder derfor som disses indbyrdes vekselvirkning «, da den efter sit væsen er »sig fra sig selv repellerende«, nødvendigvis må »afstødes« fra sig selv. ${ }^{4}$ Den på kapitalen funderede produktion sætter sig derfor »kun i sine adekvate former, såfremt og for så vidt som den frie konkurrence udvikler sig «. ${ }^{5}$ Ganske vist - »sålænge kapitalen er svag, søger den endnu selv efter krykkerne fra forgangne produktionsmåder eller fra produktionsmåder, som er forsvundet med dens fremtrædelse«. På den anden side: »Såsnart den begynder at føle og vide sig selv som en skranke for udviklingen, tager den tilflugt til former, som, idet de synes at fuldende kapitalens herredømme, gennem tæmningen af den frie konkurrence, samtidig er forkynderen af dens opløsning og af opløsningen af den på kapitalen baserede produktionsmåde«. ${ }^{6}$ I sin blomstringstid kan kapitalens herredømme imidlertid kun virkeliggøre sig i og gennem konkurrencen.

Netop denne positive kerne i konkurrencen har den borgerlige økonomi, siger Marx, »ikke begrebet «. Den frie konkurrence er af den nemlig »kun blevet forstået negativt; d.v.s. som negation af monopoler, korporation(er), lovgivningsmæssige reguleringer, osv. Som den feudale produktions negation«. Men konkurrencen »er langt fra kun at have denne historiske betydning eller kun at være dette negative«. Den er tillige »kapitalens relation til sig selv som en anden kapital, d.v.s. kapitalens reelle forhold som kapital«. Først gennem den »sættes som udvortes nødvendighed for den enkelte kapital, [. . .] hvad der modsvarer kapitalens

1. »Den anden del er nu endelig færdig. .. Det er fortsættelsen af Hefte I« [dvs. skriftet Zur Kritik der Politischen Ökonomie, MEW Bd. 13, s. 1-160], »men fremtræder selvstændigt under titlen 'Das Kapital' [. . .] Det omfatter faktisk kun, hvad der skulle være første afdelings tredie kapitel, nemlig kapitalen i almenhed. Deri er altså ikke indbefattet kapitalernes konkurrence og kreditvæsenet.« (MEW, Bd. 30, s. 639).

2. Marx' brev til Engels den 2.4.1858. (MEW, Bd. 39, s. 312).

3. Også i Theorien über den Mehrwert stilles konkurrencen og kreditten som »kapitalens reale bevægelse«, som »konkrete forhold«, op imod »kapitalen i almenhed« eller »kapitalens almene natur«. (Jvf. Theorien über den Mehrwert, MEW 26.2, s. 493, 513-514, 533-534; MEW 26.3, s. 48, 305, 348 og 455).

4. Grundrisse, 317 og 323 /dk. 166 - [I forbindelse med henvisningerne til Grundrisse der Kritik der politischen Ökonomie henvises der så vidt muligt til den danske, udvalgte oversættelse: Kritik af den politiske økonomi, Rhodos, Kbh. 1970, med angivelsen:/dk, s....] »Da værdien udgør kapitalens grundlag, og da kapitalen altså nødvendigvis kun eksisterer gennem bytning med en modværdi« - hedder det i den derpå følgende fodnote - »afstødes den nødvendigvis fra sig selv. En universalkapital uden fremmede kapitaler over for sig, med hvilke den bytter, [...] er derfor en uting. Kapitalernes repulsion fra hinanden ligger allerede i den som realiseret bytteværdi.« (Ibid., 324/dk. 169). - Altså også en »statskapitalisme« ville for så vidt kun være mulig, hvis flere statsligt organiserede kapitaler stod over for hinanden.

5. Ibid., 543 /dk. 287.

6. Ibid., 544-545/dk 288-289. - Her bliver altså af Marx - allerede i 1857 - monopolkapitalismens form forudsagt! (Man kan kalde det en »vision«; vi foretrækker det mindre mystiske ord »dialektik«). 
begreb«. Konkurrencen er derfor begrebsligt »intet andet end kapitalens indre natur [. . .], som træeder frem og realiseres i vekselvirkning mellem de mange kapitaler«, som »kapitalens immanente bestemmelser påtvinger hinanden og påtvinger sig selv«. ${ }^{7}$ Som sådan er konkurrencen »den borgerlige økonomis bevæger«, også når den ikke skaber sine love, men blot virkeliggør dem, når den ikke forklarer, men kun lader dem træde frem. ${ }^{8}$ Intet ville derfor være mere forkert end at forveksle udforskningen af disse love med analysen af konkurrencen, der forudsætter kreditforholdene, o.s.v. For at begribe fremtrædelsesformerne, må først og fremmest det, som fremtræder i dem, undersøges. Det er så meget desto vigtigere, da alle forhold fremstiller sig fordrejet og må fremstilles fordrejet i konkurrencen $^{9}$ (ikke pris bestemt gennem arbejdet, men arbejdet bestemt gennem prisen, o.s.v.), således at kapitalen i den fremtræder som "prisbestemmende, arbejdsgivende, produktionsregulerende, med ét ord [som] produktionskilde ${ }^{10}{ }^{10}$ For altså at kunne udforske de immanente love for kapitalen rent, må man abstrahere fra konkurrencen og dens følgefremtrædelser, og gå ud fra »kapital som sådan« eller fra »kapital i almenhed «. »Forekomsten af de mange kapitaler må ikke her bringe uorden i betragtningen. De manges forhold skal tværtimod forklares efter at det, som alle har fælles, at være kapital, er betragtet« ${ }^{11}$

Men hvilke er de bestemmelser, som alle kapitaler kan anses at have fælles? Åbenbart dem, som stemmer overens med kapitalen, men ikke med andre former for rigdom, hvori altså den kapitalistiske produktionsmådes bestemte historiske karakter udtrykker sig.

Økonomerne (Marx har her Adam Smith for øje) opfatter ofte kapitalen som »ophobet (genstandsgjort) arbejde«, »som tjener som middel for nyt arbejde«. Men »det er lige så umuligt at gå direkte fra arbejde til kapitalen som fra de forskellige menneskeracer direkte til bankier'en eller fra naturen direkte til dampmaskinen [. . .] For at udvikle kapitalens begreb, ${ }^{12}$ er det nødvendigt at udgå, ikke fra arbejdet, men fra værdien, nemlig det fra den allerede i cirkulationens bevægelser udviklede bytteværdi «. ${ }^{13}$ En sådan er pengene, såfremt de hverken virker som blot byttemiddel, eller stivner i skatte, men formerer sig i cirkulationen og vedligeholder sig gennem denne - formidlet af fremmed arbejde. Hvad altså først og fremmest adskiller kapitalen fra den blotte værdi eller penge, er, at den er »merværdiynglende« værdi, at der ligger et specifikt, historisk bestemt forhold til grund for

7. Ibid., 542-544/dk. 286-288: og 317. - Konkurrencen er overhovedet den måde, hvori kapitalen sætter sin produktionsmåde igennem.«(Grundrisse, 617).

8. Ibid., 450. (Jvf. H. Grossmann's udmærkede udredning i hans bog: »Das Akkumulations- und Zusammenbruchsgesetze«, Frankfurt 1967, s. 96-99).

9. „For at påtvinge sig kapitalens immanente love som ydre nødvendighed vender konkurrencen tilsyneladende alt om. Fordrejer det.«, Grundrisse, 647. - Jvf. Das Kapital, Bd. 3, MEW 25, s .55, 219, 235, 703 osv.

10. Grundrisse, 186-187.

11. Ibid., 416.

12. »Da hele den kapitalistiske produktionsmåde beror på, at arbejdet købes direkte, for i produktionsprocessen at tilegne sig en del deraf uden køb, men som man sælger i produktet - da dette eksistensgrundlag er kapitalens begreb ...«. (Theorien über den Mehrwert, MEW, Bd. 26.1, s. 265).

13. Grundrisse, 170. 
den - lønarbejdeforholdet. Frem for alt bliver »under kapital subsumeret meget, som begrebsmæssigt ikke synes at høre herunder. Kapital udlånes f.eks. Den ophobes o.s.v. I alle disse forbindelser synes den at være ren og skær ting, og helt at falde sammen med den materie, den består af «. ${ }^{14}$ Men, vi har her »hverken med en bestemt form af kapitalen at gøre, eller med den enkelte kapital til forskel fra andre enkelte kapitaler o.s.v. Vi iagttager dens opståelsesproces. ${ }^{15}$ Denne dialektiske opståelsesproces er kun det ideelle udtryk for den virkelige bevægelse, hvori kapitalen bliver til. ${ }^{16}$ De senere relationer skal betragtes ud fra denne kim «. ${ }^{17}$

Det som alle kapitaler således udviser som fælles, er deres valoriseringsegenskab - den kendsgerning, at de (direkte eller indirekte) tilegner sig den i den kapitalistiske produktionsproces frembragte merværdi. Analysen af »kapitalen i almenhed « må derfor begynde med udforskningen af produktionsprocessen. Den må vise, hvordan penge "går ud over sin simple bestemmelse som penge« og bliver til kapital, hvordan den så gennem konsumtionen af menneskeligt arbejde frembringer merværdi, og hvordan slutteligt merværdiproduktionen på sin side selv fører til reproduktionen af kapitalen og kapitalforholdet. Alt dette kan udvikles, uden at måtte tage hensyn til tilstedeværelsen af flere kapitaler og til forskellen mellem dem. For uanset hvorledes de forskellige enkeltkapitaler også deler den i produktionsprocessen frembragte merværdi imellem sig, så kan de dog "aldrig dele mere mellem sig end totalmerværdien eller totalmerproduktet «. ${ }^{18}$ Derigennem kan merværdiens opståen aldrig forklares, men kun fordunkles; thi i profitten fremtræder merværdien som frembragt ensartet gennem alle kapitalens dele, og kapitalen selv »som rigdomskilden uafhængig af arbejdet «. ${ }^{19}$ Skal altså kapitalforholdets grundforudsætninger begribes - forholdet mellem kapital og arbejde og merværdiens rolle som den kapitalistiske produktions drivkraft - så må man ikke gå ud fra »de mange kapitaler«, men fra kapitalen, respektivt fra »hele samfundets kapital «, ${ }^{20}$ altså fra kapitalen »i almenhed«. Først da er den virkelige udvikling af kapitalbegrebet muligt.

Kapitalens levnedsløb indskrænker sig imidlertid ikke til den umiddelbare produktionsproces. For at kapitalen kan forny sig, må kapitalens produkt, samt

14. Grundrisse, 412-413,/dk. 247.

15. Tilsvarende betegnes på flere steder i Grundrisse analysens egentlige genstand som »kapitalens almene opståelseshistorie«, henholdsvis dens »selvbestemmelse« eller »selvformning«. (Ibid., 307, 317 og 427).

16. "Siden vi her taler om kapitalen, den blivende kapital, har vi uden for samme endnu intet - idet de mange kapitaler endnu ikke er os for hånden - intet som den selv og den simple cirkulation ...«(Ibid., 617). - Netop i den betydning bliver i Grundrisse (men også i Kapitalen og i Theorien über den Mehrwert) den blivende til den tilblevne eller færdige kapital, - »hvorledes den træder frem som en helhed, som enheden af cirkulationsproces og produktionsproces« (Theorien über den Mehrwert, MEW, Bd. 26.3, s. 473; Bd. 26.2, s. 513-514), eller stillet op imod kapitalens »ærdige skikkelse« (Das Kapital, Bd. 3, s. 219).

17. Grundrisse, $217 / \mathrm{dk} .140$.

18. Ibid., 673. - Jvf. ibid., 576: »Profitten for kapitalisterne som klasse eller kapitalens profit må være til stede, før den kan fordeles...

19. Ibid., 645 .

20. »Og vi har her med kapitalen som sådan at gøre, say the capital of the whole society. Kapitalernes forskellighed osv. angår os endnu ikke.« (Ibid., 252). 
merproduktet, tværtimod »forvandles til penge, ikke som ved tidligere produktionstrin, hvor bytningen kun omfattede den overflødige produktion og de overflødige produkter, men på ingen måde i dens totalitet «. ${ }^{21}$ Produktionsprocessens fase må af den grund fuldstændiggøres med cirkulationsprocessens fase. Kapitalens bevægelse bliver således til et kredsløb, hvori der til den vokser nye former (fast og cirkulerende kapital), som fra at være forbigående bestemmelser af kapitalen stivner til bestemte eksistensmåder af denne. Disse former må også opfattes som forskelligheder inden for abstraktionen »kapitalen i almenhed « (»kapitalens specificering «). ${ }^{22}$ da den »karakteriserer enhver form for kapital $\aleph^{23}$ og derfor må begribes uden hensyntagen til de »mange kapitalers« vekselvirkning. - På den anden side fremtræder netop gennemløbet af cirkulationens forskellige faser gennem kapitalen "som produktionens skranke, - gennem den specifikke natur af den af kapitalen selv satte skranke«. Cirkulationen koster tid, og i denne tid kan kapitalen ikke skabe merværdi. Dens valorisering afhænger følgelig ikke kun af tidsrummet, i hvilken kapitalen skaber værdi (arbejdstid), men også af den cirkulationstid, hvori disse vædier realiseres. ${ }^{24}$ Tilsvarende fremtræder nu også kapitalens merværdi »ikke mere enkelt bestemt gennem det af den i produktionsprocessen tilegnede merarbejde«. Den bliver ikke mere målt gennem sit reale mål, »merarbejdets forhold til det nødvendige«, men ved selve kapitalens størrelse. »En kapital af en bestemt værdi producerer i et bestemt tidsrum en bestemt merværdi . $^{25}$

Merværdien antager altså nu (og vi kommer dermed til det sidste, tredie afsnit af Grundrisse) profittens forvandlede, afledte form, og merværdiraten antager profitratens form. Kun kapitalistklassens totalprofit kan falde sammen med den af den tilegnede totalmerværdi. ${ }^{26}$ Enkelte kapitaler derimod kan opnå mere eller mindre, som ville modsvare den af dem selv i produktionsprocessen frembragte merværdi. - Imidlertid henviser Marx i Grundrisse dette spørgsmål til behandling "først i betragtningen af de mange kapitaler»; da frembringelsen af en almen profitrate og dens modsvarende forvandling af værdier til produktionspriser forudsætter konkurrencen, altså finder sted på et niveau, som er udelukket ved betragtningen af »kapitalen i almenhed «, ifølge den oprindelige marxske plan. ${ }^{27}$

Som læseren kan se, taler Marx i de sidst anførte sætninger allerede om hele kapitalistklassens kapital, om den »samfundsmæssige totalkapital « - til forskel fra de særlige enkeltkapitaler. Hvilken betydning tilægges disse begreber imidlertid i den marxske metodologi? Dette ses tydeligt i en meget vigtig randbemærkning i Grundrisse:

21. Ibid., 309.

22. Ibid., 186. - Også begrebet »specificering« er et specifikt hegelsk begreb (da Marx overhovedet i brugen af termini som »almenhed«, »særegenhed«, »enkelthed« støtter sig på Hegels logik).

23. Grundrisse, 353 .

24. Ibid., 521.

25. Ibid., 632 .

26. Ibid., 673 .

27. Ibid., 645-646. 
"Kapitalen $i$ almenhed, til forskel fra de særlige kapitaler«, - læser vi her »fremtræder ganske vist 1) kun som en abstraktion; ikke en vilkårlig abstraktion, men en abstraktion, som opfatter kapitalens differentia specifica til forskel fra alle andre former for rigdom [. . . ] Det er disse bestemmelser, som er fælles for hver kapital som sådan, eller gør hver bestemt sum af værdi til kapital. Og forskellene indenfor denne abstraktion er ligeså abstrakte særegenheder, som karakteriserer enhver form for kapital, i hvilken den er dens position eller negation (f.eks. fast eller cirkulerende kapital); 2) men kapitalen i almenhed er forskellig fra de særlige, reelle kapitaler som en egen eksistens. Dette er anerkendt af den traditionelle økonomi; men ikke forstået, og det udgør et meget vigtigt moment i dens lære om udligninger o.s.v. For eksempel danner kapitalen i disse almene former, skønt tilhørende enkelt kapitalister, [. . .] den kapital, som akkumuleres i bankerne eller distribueres gennem dem, og, som Ricardo siger, ${ }^{28}$ så beundringsværdigt fordeles i forhold til produktionens fornødenheder. Den danner også gennem lån o.s.v. et ensartet niveau mellem de forskellige lande..$^{29}[\ldots]$ Medens det almene deraf på den ene side kun er tankt differentia specifica, er det samtidig en sarlig reel form ved siden af det særliges og det enkeltes form«. [...]

Og på et andet sted i Grundrisse hedder det:

»Kapitalen betragtet $\mathrm{i}$ almenhed er ikke blot en abstraktion. Betragter jeg en nations totalkapital f.eks. til forskel fra dens totalarbejde (eller også grundejendom), eller betragter jeg kapitalen som den almene økonomiske basis for én klasse i modsætning til en anden klasse, så betragter jeg den i almenhed. Ligesom når jeg f.eks. betragter mennesket fysiologisk til forskel fra dyret «. ${ }^{30}$

Den overordentlige vigtighed af disse marxske randbemærkninger er iøjnefaldende. Lad os f.eks. tage hans behandling af »den samfundsmæssige totalkapitals reproduktion og cirkulation « i Kapitalens bind II:

»Men netop fordi kredsløbet V' . . V'« hedder det der om 'Varekapitalens kredsløb', »inden for sin bane forudsætter anden industriel kapital i formen $\mathrm{V}$ (= A + Pm) [ . . ] opfordrer det selv til, at man betragter det ikke blot som kredsløbets almene form, d.v.s. som en samfundsmæssig form, under hvilken enhver industriel kapital [. . . kan blive betragtet, derfor ikke blot som en bevægelsesform, der er fælles for alle individuelle industrielle kapitaler, men samtidig som bevægelsesform for summen af de individuelle kapitaler, med andre ord for kapitalistklassens totalkapital; en bevægelse, hvori den enkelte individuelle industrielle kapitals bevægelse fremtræder blot som en delbevægelse, der fletter sig sammen med de andres bevægelse og betinges af dem. Betragter vi f.eks. et lands samlede årlige varepro-

28. Se f.eks. s. 47-48 i Ricardo's Werke (McCulloch-udgaven, 1888).

29. Marx fortsætter på dette sted: „Er det f.eks. derfor en lov for kapitalen i almenhed, at den, for at valorisere sig, må sætte sig dobbelt, og må valorisere sig dobbelt i denne dobbelte form, ja, så bliver f.eks. kapitalen en særskilt nation, som i modsætning til en anden repræsenterer kapital par excellence, og må udlåne sig til en tredie nation for at kunne valorisere sig. Denne sætten-sig-dobbelt« - tilføjer han i en hentydning til Hegel - "på sig selv som fremmed forhold, bliver i dette tilfælde fordømt reel.« Grundrisse, 353.

30. Ibid., 735 . 
dukt og analyserer den bevægelse, hvorved en del af dette produkt erstatter den produktive kapital i alle de individuelle forretninger, mens en anden del indgår i de forskellige klassers individuelle forbrug, så betragter vi V' ... V' som bevægelsesform såvel for den samfundsmæssige kapital som for den merværdi, respektive for det merprodukt, der er frembragt af denne kapital. Den omstændighed, at den samfundsmæssige kapital $=$ summen af de individuelle kapitaler [. . .] og at den samfundsmæssige kapitals totalbevægelse $=$ den algebraiske sum af de individuelle kapitalers bevægelser, udelukker på ingen måde, at denne bevægelse som bevægelse hos den enkelte individuelle kapital frembyder andre fænomener, end når den samme bevægelse bliver betragtet som en del af den samfundsmæssige kapitals totalbevægelse, altså i sammenhæng med bevægelserne hos kapitalens øvrige dele, og at bevægelsen samtidig løser problemer, hvis løsning må forudsættes, når man betragter en enkelt individuel kapitals kredsløb, i stedet for at resultere heraf «. ${ }^{31}$

Under denne synsvinkel er de enkelte kapitaler blot at betragte som »brudstykker « af den samfundsmæssige kapital, og deres »bevægelse er både deres individuelle bevægelse, og samtidig integrerende led i totalkapitalens bevægelse«, som - skønt den kun er summen af de individuelle kapitaler - udviser en forskellig karakter fra hver af de individuelle kapitalisters kapital. ${ }^{32}$ Den samfundsmæssige totalkapital « må således opfattes som en helhed, som en »reel eksistens til forskel fra de særlige reelle kapitaler«. Det samme gælder (som det allerede viste sig i den citerede randbemærkning) for den marxske betragtning af kreditten: »Det, som for den industrielle kapitals vedkommende kun træder frem i bevægelsen og konkurrencen mellem de særskilte sfærer: at den $i$ sig selv er en for klassen falles kapital, kommer her med virkeligt eftertryk frem i efterspørgslen og udbudet af kapital «. ${ }^{3{ }^{3}}$ I overensstemmelse hermed bliver kreditten af Marx betragtet som en form, »hvori kapitalen til forskel fra de enkelte kapitaler, eller den enkelte kapital som kapital, søger at sætte sig forskelligt fra sine kvantitative skranker.$^{34}$ Klarest træder den samfundsmæssige totalkapitals reelle karakter frem i aktiekapitalen, »i hvilken form kapitalen har arbejdet sig frem til sin sidste form, hvori den ikke kun er sat $i$ sig, ifølge sit indhold, men er sat i sin form som samfundsmæssig kraft og produkt «. ${ }^{35}$

Så meget om »kapitalens almene begreb « - til forskel fra betragtningen af de »konkrete forhold « ${ }^{36}$ d.v.s. »kapitalens i dens realitet «. ${ }^{37}$ Som allerede omtalt

31. Das Kapital, Bd. 2, MEW 24, s. 100-101. (Den danske udgave: Rhodos, 2. Bog 1, s. 123-124).

32. Ibid., 391 ff. (Rhodos: 2. Bog 2, s. 505).

33. Ibid., Bd. III, s. 381 (Rhodos: 3. Bog 2, s. 479).

34. Grundrisse, 551-552.

35. Ibid., 428 /dk. 225 - Her ville være at bemærke, at også modstillingen af »i sig« og "være sat« er hentet fra hegelsk logik.

36. Jvf. Das Kapital, Bd. II, s. 454 (Rhodos: 2. Bog 2, s. 583); Bd. III, s. 33, 120 osv. (Rhodos: 3. bog 1, s. 36, 142, osv

37. Forskellen mellem disse to betragtningsmåder bliver uddybet af Marx med det følgende eksempel: »Kapitalerne har forskellige størrelser. Men enhver enkelt kapitals størrelse er sig selv lig, altså for så vidt som kun dens egenskab som kapital betragtes, en vilkårlig størrelse. Men betragter vi to kapitaler adskilt fra hinanden, så indtræder et forhold af kvalitative bestemmelser gennem forskellen i deres størrelse. Den bliver selv den adskillende kvalitet. Dette er et væsentligt synspunkt, hvor størrelsen kun [er] et enkelt ksempel på, hvorledes betragtningen 
er dette begreb i Marx's øjne kun et abstrakt-dialektisk billede af »den virkelige bevægelse, hvori kapitalen bliver til«. Deraf følger, at allerede i kapitalens almene begreb »er det senere indholdt« i kimformen, altså ikke kun den »civiliserende«, fremadstræbende tendens hos kapitalen, men også de modsigelser, som fører ud over dens egne grænser. ${ }^{38}$ (Af de talrige eksempler, som man finder i Grundrisse, skal der her kun henvises til udviklingen af maskineriet, ${ }^{39}$ af kredit væsnet, ${ }^{40}$ såvel som til realiseringsproblemet. ${ }^{41}$ ) Men på den anden side får »alle kapitalens momenter, som træder frem som involveret i den, når den bliver betragtet udfra sit almene begreb, [. . .] selvstændig realitet og viser sig også først, så snart den fremtræder reelt som mange kapitaler. Den indre levende organisation, som således finder sted indenfor og igennem konkurrencen, udvikler sig da først udfra en bredere«. ${ }^{42}$

I særdeleshed bliver »samtidigheden i kapitalens forskellige udviklinger, såvel som i dens forskellige bestemmelser [.. .] først klart, så snart mange kapitaler er forudsat. Således består menneskets livsproces af et gennemløb af forskellige aldre. Samtidigt eksisterer alle menneskets aldre ved siden af hinanden, fordelt på forskellige individer ${ }^{43}$

\section{Den strukturelle forbindelse mellem Grundrisse og Kapitalen}

De læsere, som er fortrolige med indholdet af Marx's Kapitalen, vil sikkert vide at vurdere betydningen af disse uddrag af Grundrisse. Thi, hvad Marx allerede her i 1857-1859 gjorde udkast til, er i virkeligheden også programmet for hans senere værk. Som Grundrisse begrænser Kapitalens bind I og II sig nemlig i

af kapitalen som sådan adskiller sig fra betragtningen af kapitalen i forhold til anden kapital, eller betragtningen af kapitalen i dens realitet." (Grundrisse, 576).

38. "I kapitalens simple begreb må i sig være indeholdt dens civilserende tendenser osv., ikke blot, som i den hidtidige økonomi, fremtræde som ydre konsekvenser. Ligeledes de modsigelser, som senere udvikler sig, men allerede lader sig eftervise latent i det [kapitalens simple begreb].«(Ibid., 317). - Jvf. ibid., 237: »Den eksakte udvikling af kapitalbegrebet [er] nødvendig, da det som den moderne økonomis grundbegreb, ligesom kapitalen selv og dens abstrakte modstykke i dens begreb, [er] grundlaget for det borgerlige samfund. Den skarpe opfattelse af forholdets grundforudsætning må resultere i alle modsigelserne i den borgerlige produktion, såvel i den grænse, hvor den stræber ud over sig selv.«

39. Det er let at udvikle maskineriets fremkomst af konkurrencen og den af denne udløste lov om produktionsomkostningernes reduktion. Det drejer sig her om at udvikle den fra kapitalens forhold til det levende arbejde, uden hensyntagen til anden kapital.«(Ibid., 662).

40. »Modsætningen mellem arbejdstid og cirkulationstid indeholder hele læren om kreditten. . « (Ibid., 552).

41. Ibid., s. 351. - Jvf. også Theorien über den Mehrwert, MEW 26.2, s. 493: "Imidlertid, således som vi allerede fandt det ved betragtningen af pengene [. . . ] at de indeholder muligheden for kriser, så finder vi det endnu mere ved betragtningen af kapitalens almene natur, uden at de videre reelle forhold endnu er blevet udviklet, de forhold som udgør alle forudsætninger for den virkelige produktionsproces.«

42. Grundrisse, 419.

43. Ibid., 533. - Jvf. ibid., 553-554: „Kapitalprocessens samtidighed i processens forskellige faser er kun mulig gennem dens deling og afstødning i portioner, hvoraf enhver er kapital, men kapital med en forskellig bestemmelse. Denne form- og stofveksling [er] som i det organiske liv. Siger man f.eks., at legemet reproducerer sig på 24 timer, så sker det ikke på en gang, men afstødningen i den ene form og fornyelsen i den anden er fordelt, foregår samtidigt [...] (Her altså allerede overgangen til de mange kapitaler.)《 
grunden blot til den "abstrakte betragtning af kapitaldannelsesfænomenet«, ${ }^{44}$ henholdsvis til analysen af cirkulations- og reproduktionsprocessen »i dens fundamentalform «, reduceret til dens »mest abstrakte udtryk «, ${ }^{45}$ - d.v.s. til betragtningen af »kapitalen i almenhed «. (Derfor også den gennemgående antagelse, at varen sælges til sin værdi. ${ }^{46}$ ) Den egentlige metodologiske forskel begynder først med det 3. bind. Når nemlig også Grundrisse i sine sidste afsnit taler om profit, om den almene profitrate og om dennes tendentielle fald, så handler det dog stadigvæk om "profit i almenhed«, om »kapitalistklassens profit«, og ikke om »en enkelt kapitals på bekostning af en anden «. ${ }^{47}$ Disse sidste betragtninger (altså frem for alt værdiernes forvandling til produktionspriser og spaltningen af merværdien i driftsherregevinst, rente o.s.v.) fører ud over rammen for »kapitalen i almenhed«. Men Kapitalens tredie bind »nærmer sig [ . . ] skridtvis« den form, hvori »de skikkelser, som kapitalen antager [. . . på samfundets overflade, i de forskellige kapitalers vekselvirkning i konkurrencen og i produktionsagenternes almindelige bevidsthed « ${ }^{48} \mathrm{Nu}$ bliver skranken for »kapitalen i almenhed « - således som Marx opfattede dette begreb i Grundrisse - vidt overskredet. Og først nu kan de problemer angribes, som på det tidligere undersøgelsestrin blot kunne antydes, ${ }^{49}$ og hvis løsning først blev mulig gennem at trænge frem fra »de økonomiske forholds færdige skikkelse, således som de viser sig på overfladen, [. . . til deres indre, væsentlige, men tilslørede kerneskikkelse, og det dertil svarende begreb «. ${ }^{50}$

Vi tror altså i kategorierne »kapital i almenhed« og de »mange kapitaler «(det vil sige konkurrencen) at have fundet nøglen til forståelsen ikke kun af Grundrisse, men også af det senere værk, det vil sige Kapitalen. - Ganske vist bør de to værkers strukturelle slægtsskab ikke overdrives. Det bør ikke overses, at den senere omformning af den oprindelige Buch vom Kapital også førte og måtte føre til en vis ændring af denne bogs grundlæggende begreber, og at betydningen, som disse begreber har i Kapitalen af den grund ikke altid og ikke helt dækker den, som vi kender fra Grundrisse.

Javist, også i Kapitalen stilles den kapitalistiske produktionsmådes »virkelige, indre bevægelse« bestandigt op imod dens kun »fremtrædende« bevægelse, så-

44. Jvf. Das Kapital, Bd. I, s. 180, fodnote 37 (Rhodos: 1. Bog 1, s. 281).

45. Ibid., Bd. II, s. 454 og 501 (Rhodos: 2. Bog 2, s. 584 og 643).

46. »Betragtning af kapital i almenhed, hvor varens værdi forudsætter identiske priser.« (Theorien über den Mehrwert, MEW 26.2, s. 515).

47. Grundrisse, 653.

48. Das Kapital, Bd. III, s. 33 (Rhodos: 3. Bog 1, s. 36).

49. Som eksempel kan her tjene begrebsbestemmelsen af »samfundsmæssigt nødvendigt arbejde«, som - på lignende måde som begrebsbestemmelsen af akkumulationen - i første bind kun kommer i betragtning »abstrakt, dvs. som blot et moment i den umiddelbare produktionsproces« (Das Kapital, Bd. I, s. 590; Rhodos: 1. Bog, s. 802), og som først i tredie bind kan videreudvikles ud fra de »konkrete betingelsers« standpunkt.

50. Das Kapital, Bd. III, s. 219: Rhodos: 3. Bog 1, s. 270. (»Begrebet« er altså kun en afbildning af »kerneformen«, dvs. det virkeligt bestående samfundsmæssige forhold). 
ledes som konkurrencen fremstiller den. Også her bliver der konsekvent holdt fast ved den hegelske sondring mellem »væsenet« og »fremtrædelsen «. ${ }^{51}$ Vi læser i det første bind, at »man må skelne mellem kapitalens almene og nødvendige tendenser og disse tendensers fremtrædelsesformer. Vi vil ikke for øjeblikket undersøge, hvorledes den kapitalistiske produktions immanente love fremtræder i kapitalernes ydre bevægelse, hvorledes de gør sig gældende som konkurrencens tvangslove [. . .], men så meget er på forhånd klart: en videnskabelig analyse af konkurrencen er kun mulig, i det øjeblik man forstår kapitalens indre natur, - ganske som himmellegemernes tilsyneladende bevægelse kun er forståelig for den, der kender deres virkelige, men ikke sanseligt iagttagelige bevægelse «. ${ }^{52} \mathrm{Og}$ endelig hedder det i kapitel 6 af det III. bind: »De fænomener, vi analyserer i dette kapitel, forudsætter, for at de kan komme til fuld udvikling, kreditvæsnet og konkurrencen på verdensmarkedet [. . .]. Men disse mere konkrete former for den kapitalistiske produktion kan imidlertid kun fremstilles omfattende, efter at man har begrebet kapitalens generelle natur . ..." ${ }^{53}$ Hele denne ulejlighed ville rigtignok være unødvendig, »hvis tingenes fremtrædelsesform og væsen umiddelbart faldt sammen«; men da ville også »al videnskab [. . . ] være overflødig «. ${ }^{54}$ Men da det ikke er sådan, må den videnskabelige forskning trænge frem fra »fremtrædelserne i overfladen« til det »indre væsen«, til de økonomiske processers »kernestruktur «, - for på den måde at finde »fremtrædelsens lov « ${ }^{55}$ og for at begribe denne fremtrædelse selv som nødvendig. ${ }^{56}$ I denne henseende adskiller den metodologiske grundindstilling i Kapitalen sig altså ikke fra den i Grundrisse. Forskellen ligger andetsteds: deri, at Marx i Kapitalen også betragter den del af sin undersøgelse, som »skridtvis nærmer sig formerne på overfladen, i konkurrencen« (altså det 3. bind af hans værk) som hørende ind under den »almene analyse af kapitalen «, hvorigennem den sidstnævntes ramme udvides, mens konkurrencens derimod indsnævres. ${ }^{57}$ Men

51. Jvf. G. Lukács, Geschichte und Klassenbewusstsein, Berlin 1921 (Neuwied 1969), s. 20, anm. 1.

52. Das Kapital, Bd. I, s. 335; Rhodos: 1. Bog 2, s. 475.

53. Ibid., Bd. III, s. 120; Rhodos: 3. Bog 1, s. 142. - Jvf. Ibid., s. 152; Rhodos: 3. Bog 1, s. 187: »I generelle undersøgelser af denne art [som den i Kapitalen] forudsættes det i det hele taget altid, at de reale forhold svarer til deres begreb, eller hvad der er det samme, de reale forhold fremstilles kun for så vidt de udtrykker deres egen generelle type.« (Jvf. også ibid., Bd. III, s. 839; Rhodos: 3. Bog 4, s. 1070: »medens konkurrencens virkelige bevægelse ligger uden for vores plan, og vi kun har fremstillet den kapitalistiske produktionsmådes indre organisation, så og sige i dens ideale gennemsnit«.)

54. Ibid., Bd. III, s. 825: Rhodos: 3. Bog 4, s. 1052. (Jvf. Marx' brev til Engels d. 27.6.1867 og til Kugelmann d. 11.7.1868, jvf. MEW, Bd. 31, s. 313; og MEW, Bd. 32, s. 552-553).

55. Das Kapital, Bd. I, s. 325: Rhodos: 1. Bog 2, s. 461.

56. Ricardo - siger Marx i et af sine notehefter fra året $1851 \mathrm{om}$ den ricardianske betragtning af konkurrencen - »abstraherer fra det, som han betragter som akcidentielt. Noget andet er at fremstille den virkelige proces, hvori begge - det, som han kalder for en akcidentiel bevægelse, men som er det bestandige og virkelige, og dens lov, gennemsnitsforholdet - fremtræder som lige væsentlige.« (Grundrisse, 803. - Jvf. MEGA, III, s. 530-531.

57. I modsætning til Grundrisse indskrænkes altså området »læren om konkurrencen« i Kapitalen til undersøgelsen af »markedsprisernes virkelige bevægelse« (i modsætning til produktionspriser), samt til betragtningen af konkurrencekampen på verdensmarkedet. (Se Das Kapital, Bd. III, s. 120, 245, 772 og 839; Rhodos: 3. Bog 1, 2 og 4, s. 142, 311, 984 og 1070). 
det viser os, at også den i Grundrisse grundlæggende adskillelse mellem »kapital i almenhed« og de "mange kapitaler « frem for alt fremstiller en arbejdsmodel, uden hvilken Marx's økonomiske læresystem ganske vist aldrig ville være kommet i stand, men som - som enhver arbejdshypotese - kun kan gøre fordring på fuld gyldighed inden for bestemte grænser.

\section{Kurasjes bogimport}

Siden -68 har studenterbevægelsens udvikling i Vesteuropa mere og mere aktualiseret et behov for konsekvente marxistiske analyser af det kapitalistiske samfund. På denne baggrund er der opstået en omfattende pirattryksvirksomhed af klassiske marxistiske tekster, ligesom en række nye analyser udgives på forskellige små ikke-kommercielle forlag. Disse forhold gør, at mange vigtige bøger er meget svære at finde i det almindelige bogdistributionssystem.

Dette er baggrunden for oprettelsen af Kurasjes Bogimport. Vi tilstræber at holde os løbende ajour med disse forskellige udgivelser, især $\mathrm{i}$ Tyskland. De vigtigste titler samler vi i et katalog, som revideres løbende.

Du er velkommen til at skrive efter kataloget. Kender du bøger, som du ikke kan finde i det, skaffer vi dem gerne.

Bogimporten drives uden privat profit, og derfor vil vores priser altid være lave. 